\title{
ПСИХОЛОГІЧНИЙ ПОРТРЕТ СІМЕЙНОГО КОНФЛІКТУ
}

\author{
Т. О. Кругла \\ ДВНЗ «Тернопільський державний медичний університет \\ імені І. Я. Горбачевського МОЗ України"
}

У статті розкрито поняття подружнього конфлікту. Проаналізовано погляди вчених, які займалися вивченням даної проблеми. Представлені результати дослідження дозволяють стверджувати про актуальність та доцільність розпочатої науково-дослідницької роботи.

\section{PSYCHOLOGICAL PORTRAIT OF FAMILY CONFLICT}

\section{T. O. Krugla}

\section{Horbachevsky Ternopil State Medical University}

The concept of marriage conflict is exposed in the article. The looks of scientists that engaged in the study of this problem are analysed. The given results of research allow to assert actuality and appropriateness of research task in hand.

Вступ. Науковий інтерес до проблеми сімейного конфлікту значно зріс за останні роки через підвищений загальний рівень конфліктності сучасного суспільства. Проблема ця завжди була актуальною для будь-якого суспільства. Однак в Україні на всіх етапах розвитку сімейні конфлікти залишали не просто помітне місце, а, зазвичай, місце, яке відчутно впливало на її історію [1].

Актуальність дослідження підтверджується також тим, що в психологічних дослідженнях сім'і ключовим значенням $є$ проблема міжособистісних стосунків між дітьми та батьками у підлітковому віці, тому що саме в цей період перебудовується і заново структурується вся система внутрішньосімейних стосунків підлітка та його батьків. Це зумовлено не тільки віковими ознаками, але й тими соціальними процесами та умовами, в яких формується особистість підлітка.

Сучасні дослідники, С. В. Ковальов [2], О. М. Шарган [3], В. В. Столін [4], Л. М. Шипіцина [5], О. О. Бодальов [4], Е. Г. Ейдеміллер [6], А. Я. Варга [7], А. Є. Лічко [8], О. Б. Насонова [9], А. І. Захаров [10], В. І. Гарбузов [11], Т. В. Говорун [3], І. В. Добряков [6] та ін., у своїх роботах переконливо представляють залежність психічного розвитку та формування особистості дитини від батьківського ставлення до неї, стилю виховання, (с) Т. О. Кругла, 2017 батьківської позицій, стратегій і стилів сімейної комунікації взаємодій.

Як стверджують Д. Віннікот [12], Дж. Боулбі [13], Е. Еріксон [14], І. Е. Валітова [15], особливо велике значення для розвитку дитини має характер взаємостосунків із матір'ю: досягнення дитиною емоційного благополуччя, успішний пізнавальний розвиток, формування позитивного ставлення до себе та до оточуючого світу.

Сімейні конфлікти на різних стадіях становлення сім'ї мають свої характеристики, свою динаміку, свої особливості вирішення для кожного з подружжя. Попередження і вирішення сімейних конфліктів залежить від всіх членів сім'ї і насамперед від конфліктуючих сторін - подружжя.

Очевидна актуальність, недостатня розробленість та перспективність дослідження даної проблеми зумовили вибір теми наших наукових пошуків.

Основна частина. Аналіз стану теоретичної та експериментальної розробки досліджуваної проблеми дозволив виокремити певні напрямки, за якими здійснюються дослідження сімейних конфліктів у психології. Функції сім'ї та їх вплив на сімейну взаємодію розглянуто в дослідженнях А. І. Антонова [16], І. В. Гребенікова [17], Е. Г. Ейдеміллера [18], В. М. Медкова [16], А. Г. Харчева [19], В. В. Юстіцкіса [18]. Аналіз літера- 
тури свідчить, що окремі аспекти типології сімейних конфліктів відображено в працях І. В. Ващенко [20], С. М. Ємельянова [21], С. Л. Маркова [22], В. А. Сисоєнко [23], С. Г. Шумана [24].

Чимало досліджень присвячено висвітленню психотравмуючих наслідків сімейних конфліктів та ролі психологічного консультування і психотерапії при розв'язанні сімейних конфліктів (Л. Ф. Бурлачук [25], М. Пезешкіан [26], Б. І. Хасан [27], Б. Г. Херсонський [28] та ін.).

Головна ідея та основні положення концепції дослідження відображені в робочій гіпотезі, що ґрунтується на припущенні, згідно з яким психологічні передумови виникнення сімейних конфліктів мають істотні особливості та потребують науково обґрунтованих підходів до їх попередження та вирішення. Відповідно до мети дослідження нами були сформульовані такі завдання:

- розглянути поняття сімейних конфліктів;

- визначити методи досліджень сімейних конфліктів, описати їхню методику і провести аналіз результату дослідження;

- виявити причини виникнення сімейних конфліктів;

- проаналізувати ефективні методи вирішення сімейних конфліктів, спрямованих на поліпшення сімейних взаємин.

Сімейні конфлікти - це протиборство між членами сім'ї на основі зіткнення протилежно спрямованих мотивів і поглядів [29].

Вирішення сімейного конфлікту вимагає вибору, що відповідає проблемі, яка його спричинила, способу, образу дій, який відповідав би як специфіці, так і загальній природі, стандартній основі даного типу конфлікту.

Сімейні конфлікти є однією з найпоширеніших форм конфліктів. Згідно з оцінками конфліктологів, у 80-85 \% сімей відбуваються конфлікти, а в решти 15-20 \% виникають суперечки з різних причин [30].

У сімейному конфлікті партнери відчувають змішані почуття (з однієї сторони, злість, ненависть, з іншої - доброзичливі почуття, породжені досвідом попереднього спілкування) [31].

У психології ще не склалося загальноприйняте розуміння суті конфлікту. Частина психологів трактує його, як зіткнення, протидія, протиріччя [31]. Наука доводить, що сімейні конфлікти не належать до тих явищ, якими можна ефективно керувати на основі життєвого досвіду і здорового глузду.
Вітчизняні психологи визначають конфліктну взаємодію як часткову суперечність міжії учасниками, іноді й антагонізм позицій, що $є$ наслідком розбіжностей їх цінностей, цілей, мотивів [32].

Л. Петровська [33] виділила такі категоріальні підстави аналізу сімейного конфлікту: структура, динаміка, функції, типологія. Структура характеризується конфліктною ситуацією (учасники й об'єкт конфлікту) і інцидентом (відкрите зіткнення учасників конфлікту). У динаміці виділяються етапи: виникнення об'єктивної передконфліктної ситуації; усвідомлення цієї ситуації як конфліктної; інцидент; вирішення (завершення конфлікту); післяконфліктна ситуація [34]. Можна говорити про позитивну (конструктивну) і негативну (деструктивну) функціях конфлікту. Конструктивна функція полягає у встановленні джерела розбіжностей і протиріч та створенні умов для усунення конфлікту, у профілактиці стагнації відносин, стимулюванні розвитку відносин і їх оптимізації [35].

Деструктивна функція конфлікту полягає у тому, що збільшення відчуття його невирішуваності може призводити до зростаючого відчуття психологічного дискомфорту. Інакше кажучи, відбувається зсув мотиву на ціль: конфліктуючі сторони починають забувати про те, що їхньою метою є конструктивне вирішення ситуації. На рівні внутрішньосімейного функціонування деструктивна функція конфлікту може проявлятися у порушенні обміну інформацією, системи взаємозв'язків, послаблювати єдність сім'ї, знижувати її здатність протистояти труднощам тощо [36].

Сімейні конфлікти найчастіше виникають через незадоволення потреб подружжя.

Великий знавець людських стосунків Андре Моруа дуже влучно й образно змалював складнощі подружніх стосунків: два кораблі, які наблизились і розгойдуються на хвилях, борти їх зіштовхуються й риплять [37].

В. П. Ратніков вважає, що найтиповішими причинами сімейних конфліктів можуть стати такі: претензії на лідерство; розподіл домашніх обов'язків; претензії на управління бюджетом; авторитарний, жорсткий тип взаємовідносин, які склалися в сім'ї; наявність складних матеріальних проблем, які практично не можливо розв'язати; авторитарне втручання родичів у подружні стосунки; наявність протилежних інтересів, прагнень, обмеженість можливостей для задоволення потреб одного із членів сім'ї (на його думку); психосексуальна несумісність подружжя; незадоволення потреби в значущості свого «Я», неповага до почуття 
гідності з боку партнера; незадоволення потреби в позитивних емоціях: відсутність ласки, турботи, уваги і розуміння; пристрасть одного з подружжя до надмірного задоволення своїх потреб (алкоголь, наркотики, фінансові витрати тільки на себе і т. ін.); незадоволення потреби у взаємодопомозі і взаєморозумінні з питань ведення домашнього господарства, виховання дітей; розбіжності в потребах щодо проведення дозвілля, захопленнях [38].

Як свідчить практика, чим докладніше вчені вивчають сімейні стосунки, тим більше переконуються в неможливості існування безконфліктних сімей [39].

Проводячи науково-дослідницьку роботу ми спробували виявити ті основні проблемні моменти сімейного життя, які зазвичай «виносять за дужки» сімейні пари. Підтвердити думку про те, що сімейні конфлікти $\epsilon$ невід'ємною складовою життя подружніх пар.

\section{СПИСОК ЛІТЕРАТУРИ}

1. Анцупов А. Я. Конфликтология : учебник для вузов / А. Я. Анцупов, А. И. Шипилов. - М. : ЮНИТИ, 1999. - 496 с.

2. Ковальов С. В. Психологія сімейних відносин / С. В. Ковальов. - М. : Педагогіка, 1987. - С. 71-72.

3. Говорун Т. В. Батькам про статеве виховання дітей / Т. В. Говорун, О. М. Шарган. - К. : Рад. шк., 1990. - 155 с.

4. Семья в психологической консультации / под ред. А. А. Бодалева и В. В. Столина. - М. : Педагогика, 1989. 208 c.

5. Шипицына Л. М. «Необучаемый» ребёнок в семье и обществе. Социализация детей с нарушением интеллекта / Л. М. Шипицына. - СПб. : Речь, 2005. - 477 с.

6. Эйдемиллер Э. Г. Семейный диагноз и семейная психотерапия / Э. Г. Эйдемиллер, И. В. Добряков, И. М. Никольская. - СПб. : Речь, 2003. - 336 с.

7. Варга А. Я. Роль родительских отношений в стабилизации детской невротической реакции / А. Я. Варга // Вестник МГУ. Психология. - 1985. - № 4. - С. 32-39.

8. Личко А. Е. Эти трудные подростки / А. Е. Личко. - М. : Медицина, 1983. - 182 с.

9. Насонова О. Б. Становлення дитячої особистості у сімейних взаєминах / О. Б. Насонова // Вихователю про психологію та педагогіку сексуального розвитку дитини. К., 1996. - 187 c.

10. Захаров А. И. Психологические особенности диагностики и оптимизации взаимоотношений в конфликтной семье / А. И. Захаров // Вопросы психологии. - 1981. № 3. - С. 58-68.

11. Гарбузов В. И. Неврозы и их лечение / В. И. Гарбузов, А. И. Захаров, Д. Н. Исаев. - Л. : Медицина, 1977.
Висновки. Підсумовуючи викладене, можна дійти висновку, що у психології під сімейним конфліктом розуміється зіткнення протилежно спрямованих інтересів, цілей, позицій, думок, поглядів суб'єктів взаємодії чи опонентів. Аналіз літератури засвідчує, що існують різні підходи до визначення причин подружніх конфліктів, але з нашої точки зору, ще недостатньо розроблені шляхи попередження та подолання протиріч у сім'ї. Значної уваги потребує теоретичне дослідження причин виникнення подружніх конфліктів. Тому подальшим напрямком науково-дослідницької роботи є проведення аналізу результату дослідження та виявлення основних причин виникнення сімейних конфліктів, висвітлення ефективних методичних рекомендацій щодо вирішення сімейних конфліктів, спрямованих на поліпшення сімейних взаємин.

12. Винникотт Д. Разговор с родителями / Д. Винникотт. М. : Независимая фирма «Класс», 1995. - 112 с.

13. Боулби Дж. Создание и разрушение эмоциональных связей : [монография] / Дж. Боулби. - М. : Академический проект, 2004. - 232 с.

14. Эриксон Э. Трагедия личности [Текст] / Э. Эриксон. М. : Алгоритм, Эксмо, 2008. - 256 с.

15. Валитова И. Е. Психологическое сопровождение ребёнка с детским аутизмом / И. Е. Валитова // Психолог в детском саду. - 2007. - № 2. - С. 28-32.

16. Антонов А. И. Социология семьи :учебник / А. И. Антонов, В. М. Медков. - М. : Изд-во МГУ: Изд-во Международного университета бизнеса и управления («Братья Карич»), 1996. - 304 с.

17. Гребенников И. В. Основы семейной жизни : учебное пособие для студентов педагогических институтов / И. В. Гребенников. - М. : Просвещение. - 1991.

18. Эйдемиллер Э. Г. Семейная психотерапия / Э. Г. Эйдемиллер, В. В. Юстицкис. - Л. : Медицина, Ленинградское отделение, 1990. - 490 с.

19. Харчев А. Г. Социология семьи: проблемы становления науки [Текст] / А. Г. Харчев. - М. : ЦСП, 2003. - 342 с.

20. Ващенко І. В. Конфлікти: сучасний стан, проблеми та напрямки їх вирішення в органах внутрішніх справ / І. В. Ващенко. - Х. : ОВС, 2002. - 256 с.

21. Емельянов С. М. Практикум по конфликтологии / С. М. Емельянов. - СПб. : Питер, 2001. - 400 с.

22. Марков С. Л. Мистецтво творчого розв'язання сімейного конфлікту / С. Л. Марков // Молодим сім'ям (поради, консультації). - Чернівці, 1998. - 38 с. 
23. Сисоєнко В. А. Подружні конфлікти / В. А. Сисоєнко.2-ге вид., перероб. і доповн. - М. : Думка, 1989.

24. Шуман С. Г. Школьный конфликт глазами психолога / С. Г. Шуман // Педагогика. - 2001. - № 9. - С. 46-51.

25. Бурлачук Л. Ф. Психодиагностика / Л. Ф. Бурлачук. - СПб. : Питер, 2002. - 352 с.

26. Пезешкиан Н. Психотерапия повседневной жизни: тренинг разрешения конфликтов / Н. Пезешкиан. - СПб. : Речь, 2001. - 288 с.

27. Хасан Б. Ситуация обучения как продуктивный конфликт / Б. Хасан, П. Сергоманов // Вопросы психологии. 1999. - № 5. - С. 79-86.

28. Херсонський Б. Г. Психологія і психопрофілактика сімейних конфліктів / Б. Г. Херсонський, С. В. Дворяк. - К. : Здоров'я, 1991. - 192 с.

29. Бурлачук Л. Ф. Психологические особенности лиц, испытывающих затруднения при вступлении в брак / Л. Ф. Бурлачук, Л. И. Коростилева // Психологический журнал. - М., 1995. - 35 с.

30. Поликарпов В. А. Психология первой любви / В. А. Поликарпов. - Минск : Экономпресс, 2002. - 254 с.

31. Ануфриева Н. М. Социальная психология : курс лекций / Н. М. Ануфриева, Т. Н. Зелинская, Н. Е. Зелинский. 4-е изд., стереотип. - К. : МАУП, 2003. - 136 с.
32. Орбан-Лембрик Л. Е. Соціальна психологія : посібник / Л. Е. Орбан-Лембрик. - К. : Академвидав, 2003. $448 \mathrm{c}$.

33. Петровская Л. А. Теоретические и методологические основы социально-психологического тренинга : автореф. дисс. на соискание уч. степени д-ра психол. наук. - М., 1985. - 40 с.

34. Анцупов А. Я. Конфликтология : учебник для вузов / А. Я. Анцупов, А. И. Шипилов. - М. : ЮНИТИ, 2000. - 551 с. 35. Донцов А. И. Проблема конфликта в западной психологии / А. И. Донцов, Т. А. Полозова // Психологический журнал. - 1980. - Т. 1, № 6. - С. 119 - 123.

36. Елизаров А. Н. Основы индивидуального и семейного психологического консультирования : учебное пособие / А. Н. Елизаров. - Москва, 2003. - 335 с.

37. Моруа А. Превратности любви / А. Моруа. - М. : Издательский дом «Радуга», 1994. - 457 с.

38. Романова К. В. Этический мир молодой семьи / К. В. Романова. - Л. : Семья и школа. - 1985. - 185 с.

39. Либина А. Уроки семейных скандалистов / А. Либина // Семья и школа. - № 7. 